\title{
Molecular and serological study by using ELISA and rRT- PCR techniques to detect avian infectious bronchitis virus in chickens in Middle Euphrates
}

\author{
A. Abdul Aziz Abed Z. K. Shayyal \\ hassoni1996@yahoo.com \\ Coll. of Vet. Med.- Univ. of AL-Qadissiya
}

\begin{abstract}
The study was conducted to detect Infectious Bronchitis Virus (IBV) in commercial chicken farms of Middle Euphrates, the technique have been used throughout the study protocol, Enzyme Linked Immunosorbent Assay (ELISA), Real Time Reverse Transcription Polymerase Chain Reaction (RT-PCR) and histopathological study. (172) serum samples were collected from clinically infected vaccinated broiler farm and (29) serum samples were collected from clinically infected non-vaccinated broiler farm, and screened for the presence of IBV antibodies by ELISA.75serum samples from 172 samples were positive ,(43.6\%) distributed as followed $43(61.4 \%)$ from Hella, 23 (36.5\%) from Najaf and 9 (23.07\%) from Diwaneyah ,29 serum samples collected from clinically infected non-vaccinated broiler flocks, were $5(17.2 \%)$ serum positive samples for IBV. (75) tissue samples from clinically infected vaccinated broilers distributed were submitted for rRT-PCR technique, the results were as followed42 (56\%) have been detected IBV, while $30(71.4 \%)$ was positive in ELISA, and (15) samples from clinically infected non-vaccinated broilers showed 8 (53.3\%) IBV were detectable while $5(62.5 \%)$ was positive in ELISA. Also the research include study the histopathological changes of trachea, lung and kidney of infected birds which were positive for rRT-PCR.
\end{abstract}

Key words: chickens, Elisa, rRT-PCR, Middle Euphrates, Infectious Bronchitis (IBV)

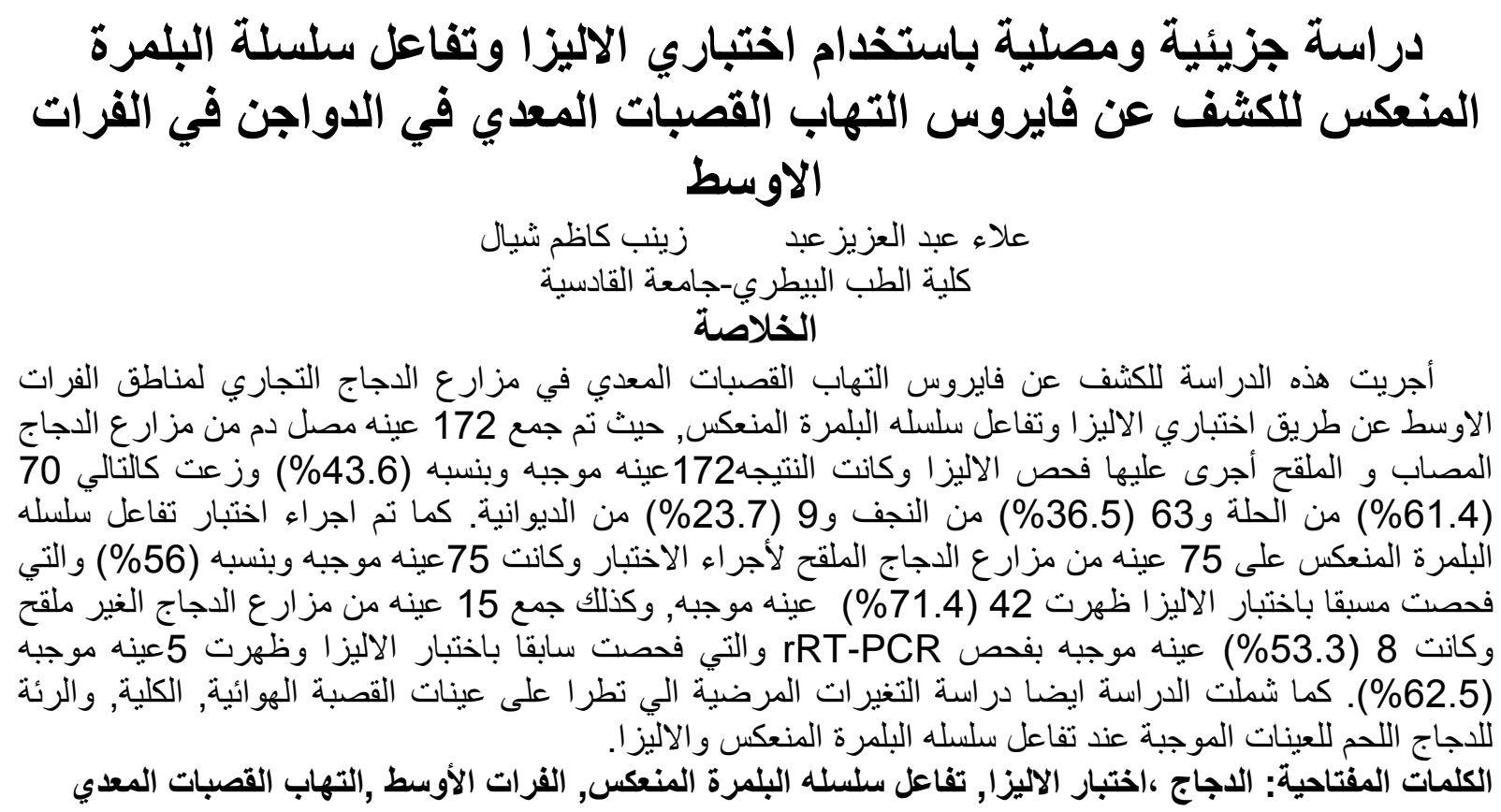

\section{Introduction}

Avian Infectious Bronchitis Virus (IBV) is a major respiratory virus of chickens it is endemic in most countries that raise chickens (1). It's host range is considered to be limited to the chicken (2), which is characterized by respiratory signs, poor weight gain and feed efficiency, and causes decrease egg production with concurrent decline in egg shell quality in layers. In broilers the morbidity rate $90-100 \%$ with weekly mortality of $5-10 \%$ (3). As the IB signs are not specific, diagnostic tools are needed to identify the IBV (4). IB is 
identified by isolation of the virus in SPF embryonated eggs or tracheal organ culture, serological and molecular method (5). More than 50 serotype of the viral have been reported in the world wide (1). So variants becomes now predominant in many countries of the world and middle-east such as Iraq (6), Egypt (7) and Jordan (8). The presence of IB in vaccinated chickens has been reported (9).

\section{Materials and methods}

Chicken flocks: Sample collection: The sample collected in November to March(2013) from infected (vaccinated and non vaccinated) birds which suffering from respiratory distress and having a mortality rate above the normal range the age of examination birds (14-34) days the collected samples include 3 province in Middle Euphrates Regions (Hella, Najaf and Diwaneyah), some of these farms nonvaccinated and another vaccinated in different vaccination program as showed in table(1). Blood samples were collected from symptoms birds which consist of $(3-5 \mathrm{ml})$ obtained from heart and vein by sterile syringes and poured in to a clean plane tube without anticoagulant and centrifuged at $2000 \mathrm{rpm}$ for 5-7minute, The serum was separated and stored in multiple marked sterile epindroff tubes at $\left(2-8^{\circ} \mathrm{c}\right)$ for ELISA test, trachea sample was collected from 90 infected birds and these tissue stored in deep freeze to prepared for RNA extraction as soon as possible.

\section{Table (1): Vaccination programs of broilers}

\begin{tabular}{|l|l|l|}
\hline $\begin{array}{l}\text { Type of } \\
\text { vaccine }\end{array}$ & $\begin{array}{l}\text { Method } \\
\text { of } \\
\text { administr } \\
\text { ation }\end{array}$ & $\begin{array}{l}\text { Age of } \\
\text { birds }\end{array}$ \\
\hline $\begin{array}{l}\text { Mixed vaccine } \\
\text { (Ma5\&Clone3 } \\
\text { 0) }\end{array}$ & $\begin{array}{l}\text { Aerosol } \\
\text { spray }\end{array}$ & 1 day \\
\hline $\begin{array}{l}\text { Mixed } \\
\text { vaccine(Ma5\& } \\
\text { Clone30) }\end{array}$ & Eye drop & 7 day \\
\hline IB 4/91 & $\begin{array}{l}\text { Drinking } \\
\text { water }\end{array}$ & 17 day \\
\hline
\end{tabular}

\begin{tabular}{|l|l|l|}
\hline $\begin{array}{l}\text { Type of } \\
\text { vaccine }\end{array}$ & $\begin{array}{l}\text { Method of } \\
\text { administrat } \\
\text { ion }\end{array}$ & $\begin{array}{l}\text { Age of } \\
\text { birds }\end{array}$ \\
\hline $\begin{array}{l}\text { Mixed of } \\
\text { vaccine } \\
(\text { H120\&B1) }\end{array}$ & Eye drop & 7 day \\
\hline IB 4/91 & $\begin{array}{l}\text { Drinking } \\
\text { water }\end{array}$ & 17 day \\
\hline
\end{tabular}

ELISA: Infectious Bronchitis Virus Antibody Test Kit,(polyclonal kit) ProFLOK IBV ELISA Kit(Synbiotics-USA) was used for the detection of specific antibody to IBV in the serum samples according to manufacturer's instruction, Briefly, $100 \mu \mathrm{l}$ of diluted samples were added to the pre-coated plate and incubated at room temperature for $30 \mathrm{~min}$. Appropriate positive and negative control was also included. After aspirating the liquid content of all wells, the wells were washed with distilled water. $100 \mu \mathrm{l}$ of AntiChicken IgG Peroxides conjugate was added into each well and the plates were incubated at room temperature for $30 \mathrm{~min}$. After washing procedure, $100 \mu \mathrm{l}$ the substrate reagent was added into each wells and incubated at room temperature for $15 \mathrm{~min}$. to stop the reaction, $100 \mu$ of stop solution was added into each well. The relative level of antibody in the sample was determined by calculating the Sample to Positive (S/P) ratio. The endpoint titers were calculated using the equation described by the manufacturer. Serum samples with S/P ratio of less than or equal to 0.2 were considered negative and those samples with $\mathrm{S} / \mathrm{P}$ ratio greater than 0.20 (titer >396) were considered positive.

RNA Extraction: The total RNAs were extracted from tracheal tissue using Accuzol reagent (Bioneer- South Korea). Briefly, at first, homogenize tissue sample in 10-20 volumes Accuzole, Then add $200 \mu \mathrm{l}$ of chloroform per $1 \mathrm{ml}$ Accuzole and shake vigorously for 15 seconds, then incubate the mixture on ice for $5 \mathrm{~min}$. after that centrifuge at $12000 \mathrm{rpm}$ for $15 \mathrm{~min}$. at $4^{\circ} \mathrm{C}$,transfer the aqueous phase to a new $1.5 \mathrm{ml}$ tube and add equal volume of isopropyl alcohol, mix by inverting the tube 4-5 times and incubate at deep freeze for $10 \mathrm{~min}$, then centrifuge at $12000 \mathrm{rpm}$ for $10 \mathrm{~min}$. at $4^{\circ} \mathrm{C}$ then remove the 
supernatant and add $1 \mathrm{ml}$ of ethanol and mix well by vortexing then centrifuge at 12000 rpm for $5 \mathrm{~min}$. then remove the supernatant, Dry the pellet at last dissolve RNA in RNAase -free water and incubating for 10 min. at 55 to $60^{\circ} \mathrm{C}$.

rRT-PCR: The IBV detection primers and prope used in this study have been evaluated previously by (10). The primers and prope sequence are as follows: IBV'5GU391 (GCT TTT GAG CCT AGC GTT), IBV5' GL533 (GCC ATG TTG TCA CTG TCT ATTG), and (CAC CAC CAG AAC CTG TCA CCTC). The RT-PCR produces a $143 \mathrm{bp}$ fragment common to all IBV in positive samples of the 5'UTR gene. One step RTPCR was performed by using amplification of target RNA. according to the manufacturer's instructions. Briefly, $50 \mu \mathrm{L}$ reaction volume per sample was prepared by adding $10 \mu \mathrm{L}$ of viral RNA template , $3 \mu$ $\mathrm{L}(25$ pmole $/ \mu \mathrm{L})$ of each downstream and upstream primers, $3 \mu \mathrm{L}$ ( 25 pmole) of probe and $31 \mu \mathrm{L}$ of DEPC water prepare after prepare the RT-PCR plate which contain (96) well and distribute these reagents (MasterMix) in volume $(50 \mu \mathrm{L})$ in each well, seal the tubes or plate using optical adhesive film for RT-PCR then completely mix by vortexing and centrifuge at 3,000 rpm, for 2 min then load the plate onto RT-PCR instrument and inside this apparatus take place three step for each step specially temperature and time (table 3) ,then give florescent light this light will be explained by the apparatus and send this information to the computer to explain this information as curve on paper

Table(2): Steps for primer in RT- PCR assay.

\begin{tabular}{|c|c|c|}
\hline Step & Condition & Cycle \\
\hline Reverse transcripition & $50-70^{\circ} \mathrm{C} \min$ & 1 \\
\hline Pre-Denaturation & $95^{\circ} \mathrm{C}, 3-5 \mathrm{~min}$ & 1 \\
\hline Denaturation & $95^{\circ} \mathrm{C}, 5-80 \mathrm{sec}$ & \\
\hline Annealing/Extension/Detection & $\begin{array}{l}55-60^{\circ} \mathrm{C}, 30-35 \\
\sec \end{array}$ & $40-45$ \\
\hline
\end{tabular}

\section{Histopathological examination:}

A thin slide of 5um thickness were prepared from kidney, trachea, lung and oviduct of birds with pathological lesions. Preparation of slides was performed according to (11). After $72 \mathrm{hrs}$ of the fixation, the specimens were washed with tap water and then processing was routinely done with a set of upgrading alcoholic concentration from $70 \%$ to absolute $100 \%$ for $2 \mathrm{hrs}$ in each concentration to remove water from the tissues, then clearance was done by xylol, then the specimens were infiltrated with semi-liquid paraffin wax at $58{ }^{\circ} \mathrm{C}$ on two stages, then blocks of specimens were made with paraffin wax and sectioned by rotary microtome at $5 \mu \mathrm{m}$ for all tissues. All tissues were stained with Hematoxylin and Eosin (H \& E) stain and the histopathological changes were observed under light microscope.

\section{Statistical analysis}

The general information the percentage of infection, ELISA and rRT-PCR results were analyzed by SPSS program, version 17 software (2010). Analytical test including the Chi-square test and T-test were used and values less than 0.05 were considered to be significant.

\section{Results and discussion}

ELISA: The ELISA assay was a convenient method widely used to detect antibody response to IBV infection in broilers flock (12). The results, based on high antibody titers in the serum by using plate coated with inactivated virions as antigen. The titer of antibodies which detected by serological methods like ELISA it depend on some important factors such as a virulent of IBV strains, nutrition, chickens health, fungal and viruses disease and repeated of vaccine (13). 172 serum samples collected from symptoms vaccinated broiler, 75 $(43.6 \%)$ were positive distributed as followed \{ 43/70(61.4\%) from Hella, 23 (36.5\%) from Najaf and $9(23.07 \%)$ from Diwaneyah \}, and remaining serum samples $97(56.39 \%)$ were negative by ELISA including 27 (38.5) from Hella, 40 (63.4\%) from Najaf and 30 (76.9\%) from 
Diwaneyah\}, 29 serum samples collected from symptoms non-vaccinated broiler flocks, 5 (17.2\%) serum positive samples for IBV and the remaining samples were negative $24(82.7 \%)$. In table(3) there was statistically significant difference $(\mathrm{P}<0.05)$ of the IgG for Hella, Najaf and Diwaneyah, if there is no significant different of value gave same letter and the different letter gave when found the significant different among the value, high percentage recorded in Hella than another regions, may be due to the intensive poultry industry of Hella province and the high frequently of IB vaccination among flocks as well as the geographical location of Hella.

Table(3): Mean Ab titers of 172 serum samples tested with ELISA distributed according location

\begin{tabular}{|l|l|l|l|l|l|}
\hline $\begin{array}{l}\text { Studied } \\
\text { regions }\end{array}$ & $\begin{array}{l}\text { Total } \\
\text { no. of } \\
\text { serum } \\
\text { sample }\end{array}$ & $\begin{array}{l}\text { No.of } \\
\text { positive } \\
\text { sample }\end{array}$ & $\begin{array}{l}\text { Abs } \\
\text { titer of } \\
\text { positive } \\
\text { sample }\end{array}$ & $\begin{array}{l}\text { No.of } \\
\text { negative } \\
\text { sample }\end{array}$ & $\begin{array}{l}\text { Abs } \\
\text { titer of } \\
\text { negative } \\
\text { sample }\end{array}$ \\
\hline Hella & 70 & $\begin{array}{l}43(61.4 \%) \\
\text { a }\end{array}$ & $\begin{array}{l}2726.93 \\
\text { a }\end{array}$ & 27(38.5\%) & 76.59 \\
\hline Najaf & 63 & $\begin{array}{l}23(36.5 \%) \\
\text { b }\end{array}$ & $\begin{array}{l}1497.60 \\
\text { b }\end{array}$ & 40(63.4\%) & 69.65 \\
\hline Diwaneyah & 39 & $\begin{array}{l}9(23.07 \%) \\
\text { b }\end{array}$ & $\begin{array}{l}2301.44 \\
\text { b }\end{array}$ & $30(76.9 \%)$ & 32.96 \\
\hline
\end{tabular}

Figures in the (vertical) row with different superscripts were significantly differed at $(\mathrm{P}<0.05)$ level.

The result of the present study was in agreement with (14), who reported that $18.02 \%$ of non vaccinated broiler chicken in Grenada were positive for IBV antibodies, also it was agreement with (15) in Duhock who collected blood from 150 samples from symptoms vaccinated and non-vaccinated flocks they found 50/120(41.64\%) serum sample positive in clinically infected non vaccinated birds and 30/30(100\%) serum sample positive in clinically infected vaccinated birds. What should be critically considered is presence of different strains of the virus (16). Also that this variance could be attributed to different climatic condition that exist in two different regions as mentioned by (17) they said some weather conditions will help in virus transmission.

rRT-PCR: The rRT-PCR has power useful in detecting several RNA viruses and become rapid methods for detection viruses directly by using avian tissue. The development of rRT-PCR method using directly avian tissues and become rapid method for detection of virus (18). In this study the one-step real time RT-PCR technique was used for detection $\mathrm{N}$ protein gene of IBV in the tissue samples (trachea and uterus), 90 samples examined in RT-PCR distributed as followed (75) sample from symptomatic vaccinated broilers distributed as $\{42(56 \%)$ have been detected
IBV, $30(71.4 \%)$ was positive in ELISA\}, and the remaining $33(44 \%)$ were negative for rRT-PCR \} and (15) samples from symptomatic non-vaccinated broilers distributed as followed $\{8(53.3 \%)$ IBV were detectable, $5(62.5 \%)$ was positive in ELISA \}, and the remaining 7 (46.6\%) were negative for rRT-PCR. Enzyme linked immunosorbent assay although faster and simple, it tend to lack specificity, sensitivity and non detect all strain or types of IBV (19). Molecular assays for the detection of IBV are commonly used because they provide highly specific and sensitive transcriptase- polymerase chain reaction (RT-PCR) to detect viral RNA directly from a clinical sample or from virus isolation in a laboratory host system. When RT-PCR is used to amplify the glycoprotein of IBV, it can coupled with restriction fragment length polymorphism or nucleic acid sequencing to identify the type of the virus (20).The results of RT-PCR indicated the highest levels of viral RNA titer because most these result located between (20.31) and cycle (42.99) and the control located in cycle(23.53) and any result excesses the cycle (40) considered negative result and these highest levels assure infection of these farms with IBV, and all result resemble as in figure (1, and 2). 


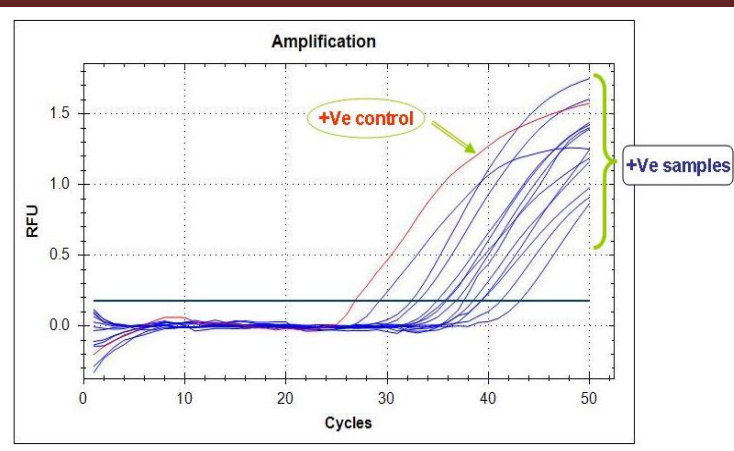

Fig. (1): Amplification plot of one step Reverse Transcription Real-Time PCR (RT-qPCR) that explains the positive results of chicken.

The results of this study were similar to (21) had examined 25 broilers flocks suffering from respiratory disease for the presence of IBV by RT-PCR and virus was detected in $(58 \%)$ of them, (22) had reported the identification and genotyping of IBV isolate in Kurdistan region of Iraq in symptomatic broiler and found poor efficacy of vaccines used in this region, since vaccinated broilers were symptomatic and found positive by RT-PCR. Our results was closely to research of, (15) who examined 80 symptomatic chickens $36(44.4 \%)$ have detectable in RT-PCR and remaining not detectable another 36 (asymptomatic vaccinated (18) and non vaccinated (18) chickens were examined by RT-PCR, $8(22 \%)$ have detectable and remaining

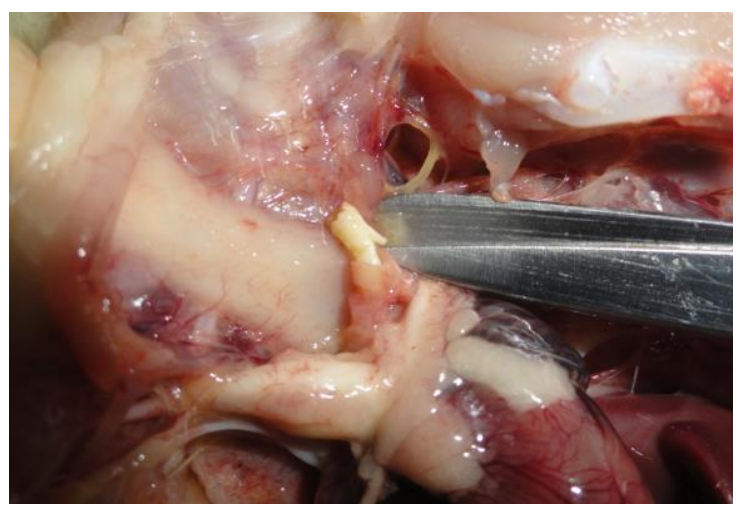

Fig.(3): Caseated plugs

Histopathology lesion: In present study the histopathological changes in trachea of infected birds were summarized by loss of cilia, sloughing and desquamation of tracheal epithelial cells with infiltration of inflammatory cells specially lymphocyte cells, hyperplasia of epithelial cells with hemorrhage, in comparison with non

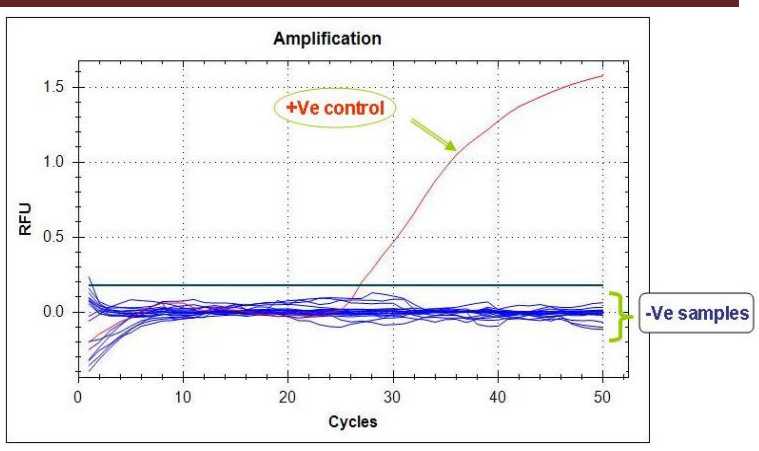

Fig. (2): Amplification plot of one step Reverse Transcription Real-Time PCR (RT-qPCR) that explains the negative results of chicken trachea

28(77.8\%) were negative but in ELISA the sensitivity was lower by detected were $50 /$ 80(62.5) were positive and remaining 30/ 80(37.5) were negative.

Clinical signs, gross lesions and Histopathological result

Clinical signs: The broilers, showed respiratory signs including, rales, coughing and gasping. Wet frothy eyes with conjunctivitis, depression and cold were also noticed.

Gross lesion: Post-mortem examination of broiler birds displayed hyperemia and congestion as well as serous exudates in the trachea of clinically infected chickens, caseated plugs at the tracheal bifurcation were also seen. Kidneys were swollen and filled with urates

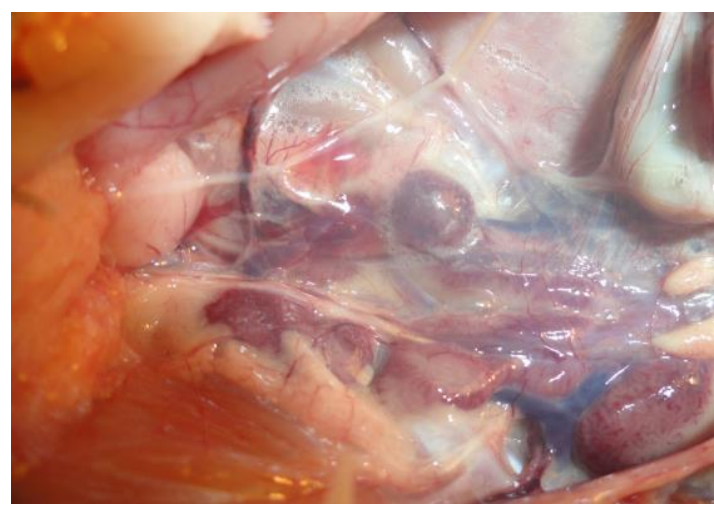

Fig.(4): Frothy exudate and cloudiness of air sac

infected birds which showed normal ciliated columnar epithelium of trachea. Saif et al., (2008) found that the congested bronchi could be attributed to the viral tropism, thus stimulated inflammatory cells (mainly lymphocytes and heterophils), which drawn to the affected area through blood circulation which induced by chemotactic factors. In 
Iraq Al- Hamadany and Qubih, (2009) who found that vaccination against IB yield histopathological changes in trachea characterized by infiltration of mononuclear cells (macrophages and lymphocytes) in epithelial and subepithelial layers as well as thickening of mucosa, with congested blood vessels. (25) showed high infiltration of lymphocytes and macrophages in the trachea. Tracheal histopathological change of the present study were in agreement of the above mentioned authors. and these finding agree with our study. The lung showed severe infiltration of inflammatory cells mostly lymphocytes and severe congestion with area of pneumonia, in comparing with the non infected lung which showed normal pulmonary tissues. These findings were similar to (26) who demonstrated IBV (QXlike strain) showed congestion and nodular or diffuse mononuclear cell infiltration was observed in lung parenchyma similar with our result. The histopathological change in kidneys were characterized by tubules degeneration, glomerular distention with severe hemorrhage and lymphocyte infiltration. These results were in agreement with (27) who reported congestion and severe granular degeneration in epithelial of kidney tubule with focal proliferation of lymphocytes around degenerated tubules. In addition these finding were also in agreement with (26) who demonstrated IBV (QX- like strain) could cause rounding and sloughing of epithelial cells deciliation with heterophils and lymphocytes infiltration and also, vacuolation and desquamation of the renal tubular epithelium with massive infiltration of heterophils. The result of histopathological examination of in the present study were showed different stages of lymphocytic infiltration ranged from (few, moderate to severe aggregations) in the renal parenchyma. (25) showed severe infiltration of lymphocytes especially in glomeruli and renal tissue due to IBV infection. These findings also in agreement with that of (28) who reported increase lymphocytic infiltration in kidney especially inside glomeruli, interstitial tissue and presence of intertubular connective tissue as a defensive mechanism against experimental infection with two IBV serotypes ( $\mathrm{T}$ and N1/88).

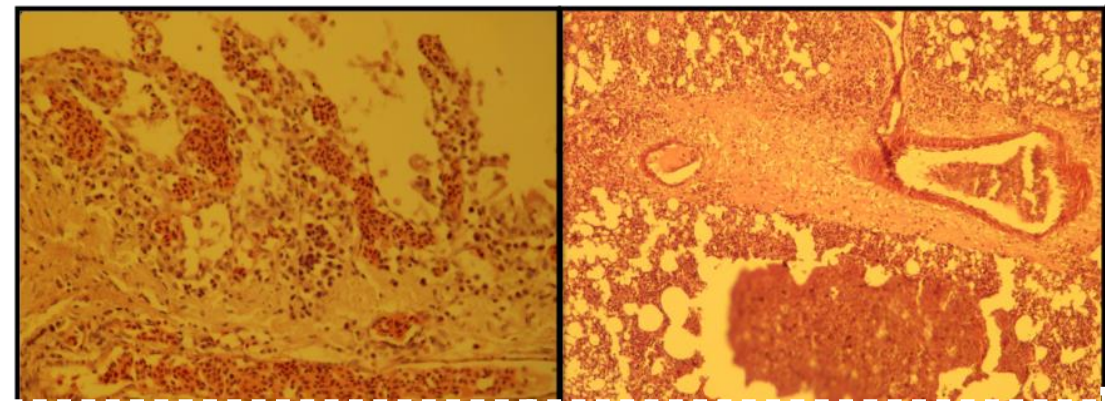

Figure (5): Trachea. Higher magnifcation, there is infiltration of inflammatory cells particularly lymphocytes and macrophage (green arrow), also there is congestion and hemorrhage (red arrow). 200X H\&E.
Figure (6): Lung. There is granulomatous lesions diffuse in the pulmonary tissue (white arrow) with infiltration of inflam matory cells particularly lymphocytes in the interstitial tissue (green arrows) and desquamation of bronchioles epithelium (red arrow). 50X H\&E.

\section{Conclusion}

This study has determined the presence of IBV in flocks of Middle Euphrates by
RT-PCR and was found very efficient in detection of infected chicken, ELISA was satisfactory for detecting specific antibodies

\section{References}

1-Cavanagh., D. (2003). Sever acute respiratory syndrome vaccine development: experiences of vaccination against avian infectious bronchitis coronavirus, Avian Pathol. 32:567-582.

Figure (7): Kidney. Higher magnification, high infiltration of lymphocytes (red arrows) and macrophage (green arrows) in the glomeruli and renal tissue. 200X H\&E.

2-Cavanagh, D. and Naqi, S. (2003). Infectious bronchitis, In diseases of poultry, Saif, Y. M., Barnes, H. J., Glisson, J. R., Fadly, A.M.,McDougal, L.R. and D.E. Swayne, eds. 
(Ames, Iowa: Iowa state university Press), pp 101 119.

3-Zanella, A.; Lavazza, A; Marchi, R.; Moreno Martin, A.; Paganelli F.(2003). Avian infectious bronchitis: characterization of new isolates. Avian Diseases 47: 1, 180-185

4-Momayez, R.; Gharahkhani, P.; Toroghi, R. and Pourbakhsh, S.A.(2005).Detectionof IBV, in allantioc fluid by Rapid heamagglutinate test. Arch. Razi Ins. 59:47-54

5-Keeler, C.; Reed, K.L.; Nix, W.A. and Gelb, J.(1998). Serotype identification of avian infectious bronchitis virus by RT-PCR of the peplomer(S-1) gene. Avian Dis.42(2), 275-284.

6-Al-Husairaji, F.F. (2005). Isolation, identification and pathogenesis of infectious bronchitis virus in broilers in Northern area of Iraq. M. Sc. Thesis College of Veterinary Medicine -Mosul University - Iraq.

7-Mahgoub, K.M.; Khaphagy, A.; Bassiouni, A. and Negwa, R.S.(2010). The prevalence of infection bronchitis (IB) outbreaks in some chicken farms. II. Molecular characterization of field isolate IB virus. J. American Science.6:71-93.

8-Roussan,D.A., Totanji,W.S, and Khawaldeh,G.Y. (2007). Molecular subtype of infectious bronchitis virus in broiler flocks in Jordan. Poult. Sci. Asso.87:661-664.

9-Alvarado, I.R.; Villegas, P.; El- Attrache, J. and Brown, T.P.(2003). Evolution of the protection conferred by commercial vaccines against the California 99 isolate of infection bronchitis virus Avian Diseases Diseases, 47, 1298-1304.

10-Callison,S.A.; Hilt,D.A.; Boynton, T.O; Sample, B.F; Robison, R.; Sawayne, D. E. and Jachwood, M.W.(2006). Development and evolution of realtime Taqman RT-PCR assay for the detection of infectious bronchitis virus from infected chickens. Journal virological Methods 138:60-65.

11-Luna, L.G.(1986). "Manual of Histologic Staining Method of the Armed Force Institute of Pathology ". 3 Ed. McGraw-Hill, New York

12-Wing,C.H.,Hong,C.C.,andSeak,J.C.H..(2002).An ELISA for antibodies against infectious bronchitis virus using an $\mathrm{S} 1$ spike polypeptide.Vete. Microbio.85:333-342.

13-Chen, H.; Coote, S. and Hiscox, J.A. (2003).Evalution of a nucleoprotein-based enzyme-linked immunosorbent assay for the detection of antibodies against infectious bronchitis virus. Avian Pathol., 32:519-526.

14-Sabrainath,A.S.,SabrainathG.P.,Tiwari,K.P.,

Kumtherkar,S.M.Thomas,D.andSharma,R.N. (2011). Seroprevalance of infectious bronchitis virusin birds of grenada . Int. J.Poult.Sci. 10(4)266-268.

15-Al-Barwary, D.A.M. and Goreal, A.A.(2012). Diagnosis of infectious bronchitis disease in broiler chickens by serological test (ELISA) and RT-PCR in Duhock. Journal of Animal and Veterinary Advances, 4(1): 71-75.
16-Seyif Abed Shapouri, M.R.M.; Mayahi, S.; Charkaher and Asasi, K. (2002). Serotype identification of recent Iranian isolate of infectious bronchitis virus by type-specific multiplex RTPCR. Arch. Razi Ins., 53:79-84.

17-Hadipour,M.M.,Habibi,G.H.,Golehin,P.,Hadipourfard,M.R.,andShayanpour,N.(2011).The role of avian inf. inflauenza.Newcastle dis. and inf. bronchitis viruses during the respiratory disease outbreak in commercial broiler farms of Iran Int.J.aAnim.Vet.Adv.,3:69-72.

18-Falcon, E.; Dqamore, E.; Di Trani, L.; Sili A. and Tollis M. (1997).Rabid diagnosis of avian infectious bronchitis virus by polymerase chian reaction. Journal of virology methods. 64:125-130.

19-Naqi, S.A.; Karaca, K. and Bauman, B. (1993). A monoclonal antibody- based antigen capture enzyme -linked immunosorbent assay for identification of infectious bronchitis virus serotype. Avian Pathol.22, 555-564.

20-Kingham, B.F.; Keeler, C.L.; Nix, W.A.; Ladman, B.S. and Gelb, J.(2000). Identification of avian infectious bronchitis virus by direct automatic cycle sequencing of the S-1gene. Avian Dis.44(2), 325-335.

21-Roussan, D.A.; Khawaldeh, G.Y. and Sahahen, I.A.(2009).Infectious bronchitis virus in Jordanian chickens: Seroprevalence and detection. Can.Vet.J., 50:77-80.

22-Mahmood, Z.H.; Sleman, R.R. and Uthman, A.U.(2010). Isolation and molecular characterization of Sul/01/09 avian infectious bronchitis virus, indicates the emergence of a new genotype in the middle East.16:7-21.

23-Saif,Y.M.,Barnes,H.J.Glisson,J.R., and Swayne ,D.E.(2008).Diseases of Poultry"12 ${ }^{\text {th }}$ Ed.,Iowa State Univ.PressBlackwell Publishing Company,Iowa,USA, 117-129.

24-Al- Hamadany, S.M. and Qubin, T.S.(2009).Histological study on the effect of Infection bronchitis vaccine strain H120 in broilers . IraqJ.Vet.Med., 23(2): 333-337.

25-Chen, B.Y. and Itakura, C. (1997).Histopathology and immune histochemistry of renal lesions due to avian infectious bronchitis virus in chicks uninoculated and previously inoculated with highly virulent infectious bursal disease virus," Avian Pathology, vol. 26, no. 3, pp. 607-624.

26-Zsofia, B.; Tamas, M.; Tibor, S.; Eva, S.; Veronik, K.; Zsolt, A.; Miklos, R. and Vilmos, P.(2009). Comparison of the pathology of QX- like, M41 and 793/B infectious bronchitis strain from differentpathological condition. Avian pathol.68:22-29.

27-Zhou, J.Y.; Zhang, D.Y.; Ye, J.X. and Cheng, L.Q.(2003). Characterization of an avian infectious bronchitis virus isolated in China from chicken with nephritis. J.Vet. Med. 51:147-152.

28-Chusalkar, K.K.; Roberts, and Reecet, R.(2007). Comparative histopathology of two serotypes of infectious bronchitis virus ( $\mathrm{T}$ and $\mathrm{N} 1 / 88$ ) in laying hens and cockerels. Poult. Sci. J., 86: 50-58. 